\title{
A Research Proposal to Examine Entrepreneurship in Family Business
}

\section{Jorge A. Durán-Encalada*, Juan M. San Martin-Reyna**, \\ Héctor Montiel-Campos ${ }^{* * *}$}

\begin{abstract}
This paper builds on existing theoretical and empirical studies in the areas of family business and entrepreneurship. It uses Dubin's theory building framework to propose a model for conducting research of family businesses and its linkage to entrepreneurial activities in Mexico. This works starts by describing the concepts of family business and explains the importance that these definitions can have on the variables to be included in the research. After that, the paper explains how the concept of "familiness" relates to the essence definition of family business. Using the resource-based view (RBV), agency theory, and social capital theories we describe how social capital resources are the basis for building firm capabilities and competitive advantages that influence firm's performances. Based on this perspective, a theoretical model, laws of interaction, a set of propositions and suggestions for further research are provided.

Keywords: entrepreneurship, family business, familiness, business performance.
\end{abstract}

\section{Introduction}

This work seeks to explore different approaches to entrepreneurship in family businesses. In this way, it contributes to a research program on family business that is underway at the Family Business Research Center in the Universidad de las Américas Puebla. This program has the purpose of finding out the specific characteristics of factors associated to entrepreneurship in the context of family businesses in Mexico. This paper utilizes Dubin's (1978) theory building framework to propose a model to examine entrepreneurship in family business. We include a revision of some theoretical constructs that have been directed at examining the relationship between factors associated to family businesses and actions related to entrepreneurship in these same firms. In order to do so, we can see initially that according to the way that

\footnotetext{
* Dr. Jorge A. Durán-Encalada, Family Business Research Centre - Universidad de las Américas Puebla, jorgea.duran@udlap.mx

** Dr. Juan M. San Martin-Reyna, Family Business Research Centre - Universidad de las Américas Puebla, juanm.sanmartin@udlap.mx

*** Dr. Héctor Montiel-Campos, Family Business Research Centre - Universidad de las Américas Puebla, hector.montiel@udlap.mx
} 
a family business is conceptualized, this will define those business family factors that will become relevant in the model (units of the theory).

Also, from a theoretical standpoint, those factors play a distinctive role in defining the strategic path that the family business follows and the process that takes place to arrive at strategies, namely, the strategic planning process. Therefore, we review some works that include the strategic planning as a mediating process between the family business factors and entrepreneurial actions. Based on these works, we made a theoretical model proposal to classify business family attributes and factors and how these relate to entrepreneurial activities that are undertaken by the firms (laws of interaction). After that, it is necessary to define the boundaries of the model and explain the conditions under which the theory is operative. Finally, based on this proposal, we present some empirical results that provide elements to build research propositions. These theoretical propositions will allow us to conduct further research on entrepreneurship in family business in Mexico.

The objective of this paper is, therefore, to build a model for conducting research of family businesses and its linkage to entrepreneurial activities in Mexico. Regarding the organization of the paper, it proceeds as follows. After introduction, we describe briefly Dubin's methodology for building theory. In the next section, we develop the structural components of Dubin's model- We shall conclude our paper by discussing the results and the conclusions conducted in this research.

\section{Dubin's methodology for theory building}

In this research we use the Dubin's (1978) methodological approach. Dubin provides a comprehensive methodology for theory building from a literature review perspective. It is particularly relevant for applied fields such as management, marketing, and organization theory. Dubin's methodology has eight phases for building theory, and these are: (1) units (i.e., the main concepts) of the theory, (2) laws of interaction (among the concepts), (3) boundaries of the theory (the boundaries within which the theory is expected to apply), (4) system states of the theory (conditions under which the theory is operative), (5) propositions of the theory (logical deductions about the theory in operation), (6) empirical indicators (empirical measures used to make the propositions testable), (7) Hypotheses (statements about the predicted values and relationships among the units), and (8) research (the empirical test of the predicted values and relationships).

In order to reach the objective of this research, we use the first five phases of the methodology because these represent the structural components of Dubin's model. The last three phases represent the process of empirical validation. Some theorists consider the eight phases of Dubin's model for effective theory building; however, theory building and empirical research are often separated, and each of these in conducted as a distinct research effort. 


\section{Elements of a model to examine entrepreneurship in family business}

We describe in this section the development of the model to examine entrepreneurship in family business using the first five phases of Dubin's methodology for theory building.

\section{Units of the model}

The units of the model are the ideas, concepts and previous research, from which the model is constructed. To determine the concepts in our model, we reviewed academic papers on family business and entrepreneurship in leading academic journals and annual conference proceedings. Our review indicates that the literature includes several related concepts.

\section{Family business concept}

In order to examine the literature related to entrepreneurship in family business, we take as a basis the philosophical difference made by two approaches to define a family firm: the components of involvement and the essence approach (Chua, Chrisman and Sharma, 1999; Habbershon, Williams and MacMillan, 2003). The components of involvement approach has been the most influential approach in conducting research in the family business field, including those aspects related to strategic planning and entrepreneurship. It focuses on combination of variables related to the type and degree of ownership, type of governance and management, and trans-generational succession issues as distinctive attributes that identify a family business (Chua et al., 1999). The essence approach, on the other hand, considers that those variables, even though necessary, are not sufficient for identifying it as a family business. Therefore, it should also take into account matters related to intention, vision, behavioral aspects, and "familiness", which are intrinsic to its nature to qualify as such (Davis and Tagiuri, 1989; Litz, 1995; Chua et al., 1999).

Familiness is a concept that was first proposed by Habbershon and Williams (1999), who defined it as the unique bundle of resources and capabilities a particular organization possesses because of the family system's interaction among the family, its individual members, and the business. It is clear from these concepts that the components of involvement approach has created more opportunities for conducting research as the variables associated with the concept implicit in the approach are more amenable to become operational. However, for the case of the essence approach to be used as a basis for research, some theoretical underpinnings must be explained before that is attempted.

\section{Theories associated with the essence approach}

Various works have indicated that family business features can be examined under the lens of the resource-based view (RBV) and agency theories. The RBV of the firm suggests that returns achieved by firms are largely attributable to their resources (Penrose, 1959; Hitt and Ireland, 1985; Wernerfelt, 1984; Grant, 1996). RBV lends 
support for associating some features with family firms which allows them to display more valuable resources and capabilities that are the basis of a solid competitive advantage through an appropriate strategy in comparison to non-family businesses (Haynes, Walker, Rowe and Hong, 1999; Cabrera, De Saa and Garcia, 2001; Habbershon and Williams, 1999; Aldrich and Cliff, 2003). As part of these features, we have the high degree of family members' commitment and dedication, as well as customers' trust and perception as characteristics of family business (Ward, 1987; Leach, 1993; Gallo, 1995). These resources and capabilities are sustained by the unique resources attributes that family firms possess: human capital, social capital, patient capital, survivability capital and governance structures (Sirmon and Hitt, 2003).

Agency theory adds to the RBV by reducing or eliminating the agency costs that are normally present when the property and the administration of a business are in the hands of people who are not related by kinship (Jensen and Meckling, 1976; Myers, 1977; Becker, 1981; Shleifer and Vishny, 1997). In family business, as these roles are exercised by the same family members, there is a large identification between the economic and non-economic objectives of owners and the business administration (Fama and Jensen, 1983; Pollack, 1985; Schulze, Lubatkin and Dino, 2001, 2003). Pearson, Carr and Shaw (2008) complement the RBV and agency theories with the social capital theory in order to explain the content of familiness. They take the definition of social capital as "the sum of actual and potential resources embedded within, available through, and derived from the network of relationships possessed by and individual or social unit (Nahapiet and Ghoshal, 1998, p.243)." As a result, Pearson et al. (2008), based on other works (Arregle, Hitt, Sirmon and Very, 2007; Leana and Van Buren, 1999; Nahapiet and Ghoshal, 1998; Oh, Labianca and Chung, 2006) provide a social capital model of familiness and the parameters to implement this construct.

This model explains the structural, cognitive, and relational dimensions of social capital that serve as the behavioral and social resources that constitute familiness. The structural dimension comprises the social interactions, including the patterns and strength of ties, among the members of a collective integrated by the family. The cognitive dimension includes resources providing shared representations, interpretations, and systems of meaning among the family parties. The relational dimension that integrates the prior two dimensions consists of resources created through personal relationships, including trust, norms, obligations, and identity. These resources lead to a capability that consists in access to broader sources of information and improved information quality, relevance, and timeliness, on the one hand, and encourages willingness and ability of participants to subordinate individual goals and associated actions to collective goals and actions, on the other. In addition to addressing these dimensions, Pearson et al. (2008) indicate the antecedent conditions that help to create familiness. These comprise: (1) the family's existing structure and long-standing internal relationships that help to build the stability necessary to generate social capital; (2) interdependence that is largely a function of the joint and shared interests and the agreement toward shared goals that members of a collective have; (3) frequent and close social interactions that permit actors 
to know one another, to share important information and to create a common point of view; and (4) closure that can be interpreted as the degree to which boundaries exist, which prevent external influences and enhance internal focus on such management activities as information sharing and decision making.

In this work we take the social capital resources represented by the dimensions included in the social capital model of familiness to relate them to the building of entrepreneurial capabilities. In fact, as we will see later, information access and associability capacities, identified by Pearson et al. (2008) as the building blocks of capabilities, are important for conducting entrepreneurial type of activities in the family firm.

\section{Demographic factors}

The demographic factors represent the structural dimension of social capital resources, and these include age, time of tenure, founder-manager role, educational level of owner-manager, the number of generations involved, and the degree of ownership by the family owner. In general, there was not a significant relationship of ownermanager's age with entrepreneurial behavior (Kellermanns, Eddleston, Barnet and Pearson, 2008), even though in a study (Wang and Poutziouris, 2010) age was found to be negatively related to entrepreneurship. In this latter case, it was argued that risk taking behavior for young entrepreneurs may enhance their reputation and prestige within the firm and give further security to their leadership position. CEO tenure in the organization was negatively associated to entrepreneurship, as the behavior of longer tenured CEOs may be reflecting greater caution as they focus on succession issues, which in turn would lead to lower growth (Kellermanns et al., 2008; Zahra, 2005). However, Wang and Poutziouris (2010) found a positive relationship, as long tenure creates opportunities for owner-managers to identify externally generated valuable knowledge that is critical to the business operations and then absorb, assimilate and integrate it to the business processes.

The duality of being a founder and CEO did not appear to have any bearing on entrepreneurial risk. This may be due, on the one hand, to the fact that even though it preserves the experiences and values of the founder necessary for undertaking new initiatives, it also centralizes authority in the hands of the CEO and prevents others from contributing to entrepreneurial activities (Zahra, 2005). The number of generations involved in the firm's management positions was positively associated to entrepreneurship (Kellermanns et al., 2008), and to higher risk taking (Wang and Poutziouris, 2010). The higher the number of generations from the owner family in control or operating within the company, the higher the firm's focus on entrepreneurship (Zahra, 2005; Wang and Poutziouris, 2010). One interpretation of this finding is that different and multiple generations bring fresh insights and experiences and, therefore, new knowledge into the family firm. Finally, entrepreneurs' educational level and owner family's degree of ownership were neutrally related to entrepreneurship (Wang and Poutziouris, 2010). 


\section{Institutional factors}

The variables included as institutional refer to ownership and governance systems and are considered as part of the structural dimension of social capital resources. We present the results of an influential research carried out by Zahra, Neubaum and Huse (2000). Stock ownership appeared to motivate executives to promote value-creating activities such as corporate entrepreneurship, which can enhance the wealth of the firm and its executives. Stock ownership by "pressure-sensitive" institutions (insurance companies, banks and non-bank trusts) was negatively associated with entrepreneurship. The business relationship they have with the companies in their portfolios might compromise their willingness to challenge and influence management to support long-term corporate enterprise initiatives. However, "pressure-resistant" institutional owners (public pension funds, mutual funds, endowments and foundations) encouraged and challenged senior executives to pursue corporate entrepreneurship. There was a positive relationship of board size and corporate entrepreneurship until a certain threshold (11 members) was reached in which case the relationship became negative. The negative association may reflect the difficulties that directors in large boards encounter in communicating and participating in the board's deliberations. The higher participation of outside directors in the boards was negatively associated to entrepreneurship. Their detachment from managerial decisions might prevent them from exercising influence and increase their dependence on the company executives' conservative-laden decisions. Increasing the outside directors' stock ownership acted as an incentive to understand the company's operations and strategic moves, especially in the realm of corporate entrepreneurship. Finally, separation of the company CEO and board chair position was associated positively with entrepreneurship. This situation may increase diversity of opinions, empower the board and increase its independence from the CEO.

\section{Organizational factors}

In order to complement the structural dimension of social capital resources, we will examine studies that have taken into account factors related to organizational structure characteristics and how these relate to entrepreneurship. Organizational characteristics and their association with entrepreneurship vary according to whether firms were classified as "founder-centered" (FC), "sibling/cousin consortium based" (CB) or "open family" (OF) (Salvato, 2004). In relation to organizational and governance issues the FC firms needed support from both family and non-family members of the organization to proactively devise innovative business ideas, and to take risks of pursuing them. In the $C B$ case, firms were characterized as being in the path towards managerialization, yet still characterized by considerable levels of informality. Such an organizational hybrid proved beneficial for the levels of entrepreneurship. In the OF firms, there was a tendency towards compensating employees according to the value they add to the firm that was positively related to entrepreneurship. 
Another organizational study was carried on by Miller (1983) who examined how the organization structure and type of environment modify the nature of entrepreneurship in different types of firms classified, according to Mintzberg (1973, 1979), as "simple", "planning" and "organic". In simple firms the locus of control, centralization and individual-scanning were very significantly correlated with entrepreneurial activity. Also entrepreneurship was so very tied up with the leader's personality power and information that almost nothing else seemed to count. Issues of technocratization were linked to entrepreneurship by the role played by external consultants, such as scientists, engineers or market experts. In the planning firms, there was a high correlation of entrepreneurship with the explicitness of strategy, even though the stable environment in which these firms operated did not serve as a stimulus to entrepreneurship. In organic firms, the level of entrepreneurial activity was tailored to the demands of the environment. Organizational structural variables (communication, differentiation, delegation of authority, technocratization and decentralization) correlated highly with entrepreneurship. Decision making power was so diffuse in these firms that the personality of the leader did not have a significant impact upon entrepreneurship which was performed by many individuals at many levels.

\section{Behavioral and cultural factors}

Now, we examine the cognitive dimension of the social capital resources considering the research that has focused on the relationship of behavioral and cultural factors with entrepreneurship. The ability to recognize technological opportunities, pursue organizational change, and exploit opportunities through strategic planning increased corporate entrepreneurship in family firms (Kellermanns and Eddleston, 2006). Family firms' willingness to change was an additional factor that increased corporate entrepreneurship (Kellermanns and Eddleston, 2006), and considered a characteristic that firms are often criticized for lacking. In relation to this issue, Shepherd and Haynie (2009) argued that many times firms face an identity conflict that opposes "who we are as a family" with "who we are as a business". In order to help solve this conflict, they proposed a model of a meta-level identity that deals gradually with the source of identity conflict and ultimately eliminates it. However, they also recognized that its application would likely result in a decline in the frequency of conflict-triggering opportunities discovered by the family business, suggesting that the nature of opportunities discovered by the business may represent more incremental (less novel) opportunities for growth. Results showed that family firms' individual -versus- group orientation had an inverted U-shaped relationship with entrepreneurship (Zahra, Hayton and Salvato, 2004).

Family firms whose cultures strongly favored an individual orientation might have found it easy to spur the entrepreneurial initiatives deriving from the autonomous action of the managers and employees. But these firms might have found it difficult to build the cooperation necessary to implement these activities. Therefore 
entrepreneurship flourishes at moderate levels of individualism and family businesses may benefit from balancing these opposite cultural orientations. High external cultural orientation was positively associated with entrepreneurship in family firms (Zahra et al., 2004). This culture values new knowledge acquired from customers, suppliers and competitors (Morris, 1998). Financial controls, a proxy for short-term orientation, lowered entrepreneurship, whereas there was a positive association between strategic control and entrepreneurship, indicating the importance of a long-term cultural orientation (Zahra et al., 2004).

\section{Social network factors}

We examine now the relationship between social network factors and entrepreneurship. The variables associated with social network represent the relational dimension of the social capital resources. Toledano, Urbano and Bernadich (2010) suggested that the promotion of trust of owner-managers in the organizational context may assume the role of intrapreneurs as network or human interaction builders within business, in order to promote corporate entrepreneurship through collective activities. In relation to social networks, Klyver (2007) considered the changes in the involvement of family members in an entrepreneur's social network during the entrepreneurial process. He used a "life cycle" approach represented by four phases for explaining behavior in the entrepreneurial process: "discovery", "firm emergence", "baby-business" and "operating". His research showed that family members counted as the most frequent role-relation in social networks during the entrepreneurial process, and their involvement tended to be more common in the firm emergence phase than in the others. They tended to be more critical than other players in their role-relationships. Family involvement was most common when entrepreneurs were young and had higher education of three years or above. As the discovery phase is more a cognitive and individual process, weak bridging ties and not strong family-based ties are needed (Evald, Klyver and Svendsen, 2006).

The emergence phase demand, on the other hand, is characterized by strong and emotional supportive ties typically provided by family members, where human, financial and physical resources have to be obtained. Further on, the baby-business and operating phases are driven by commercial type of ties. According to Anderson, Jack and Dodd (2005), the level of involvement in these networks is not limited only to family business members, whether we consider a narrow, middle, and broad family definition (Astrachan and Shanker, 2003). Involvement should consider also those family members who are beyond the family business boundaries, that he called the "family jugglers" group. These are in an intermediate position located between familyinside and family-out (Birley, Ng and Godfrey, 1999). Anderson et al. (2005) results showed that well over two-thirds of the family members to whom entrepreneurs turned for help with their business work outside the formal boundaries of the family firms. Indeed, for some topics, they were more likely to seek discussions with family than with business ties. 
These subjects were found to be tax issues, production and operations, and managing staff. Family help was more likely to be emotional support than help from business contacts, and this was provided often in the form of advice, problem solving, and information. With the inside-family, strong, high-quality, opportune, non-cost, and professional links were set up, but these contributions were limited in scope and were of a homogeneous nature. With the jugglers, even though links were weaker, their advice included the heterogeneity of resources and viewpoints. Additionally, these maintained the high quality of advice, the rapidity of the service provided, and low or nonexistent costs. Issues related to taxes, promotion and advertising, operations management, managerial personnel, were included in these interactions. Although there was mainly a strong emotional content in these contacts, these did not suppress others related to consulting, problem resolution, and information.

\section{Entrepreneurship and performance}

Most studies that have focused on examining the linkage between family firms and entrepreneurship have taken the concept developed by Miller (1983). According to Miller (1983), entrepreneurship is a multidimensional concept that encompassing the firm's actions relating to product-market and technological innovation, risk taking and proactiveness (Miller, 1983). Lumpkin and Dess (1996) defined these concepts as follows. Innovativeness indicates the firm trend to support new ideas and foster creative processes that aim to develop new products and services. Risk taking is the firm tendency to support projects in which profits are uncertain. Proactiveness means taking initiative and pursuing new business opportunities in emerging markets. Actually, with similar connotations, the term entrepreneurship in the context of family firms has been referred to as corporate entrepreneurship (Zahra et al., 2000; Kellermanns and Eddleston, 2006), entrepreneurial behavior (Kellermanns et al., 2008), entrepreneurial orientation (Naldi, Nordqvist, Sjöberg and Wiklund, 2007), or entrepreneurial spirit (García-Tenorio and Sánchez, 2009).

Most recently, and based on a concept that implies social capital and familiness connotations, the term collaborative entrepreneurship or collective entrepreneurship has been used to refer to entrepreneurship (Johannisson, 2003; Ribeiro-Soriano and Urbano, 2009; Toledano et al., 2010). Concomitantly, scholars have begun paying more attention to entrepreneurial activities that take place within an established organization, using the term of intrapreneurship in these cases. As such, collaborative entrepreneurship "encompasses the relationships established among individuals in order to create new business within established firms, introduce significant innovations and enhance a company's competitive position" (Toledano, et al., 2010, p. 398). This concept emphasizes the role of human interactions or networks that are built around the family business and contains elements more closely related to the essence approach of family firms. In addition to the factors related to innovation, risk taking and proactiveness, mentioned above, collaborative entrepreneurship considers frequency and type of interactions, 
network access and openness, nature, occupation, and content of tie contact, among other relevant variables.

In relation to family firm performance associated with entrepreneurship, indicators as profitability (return on assets -ROA-, return on equity -ROE-, return on sales ROS-, and earnings per share -EPS-), growth (employment, sales, profits, value), and others, such as cash-flow and the Tobin's q, have been used in those studies. A closer examination shows that the effects of entrepreneurship on different performance metrics vary according to the length of time considered for analyzing these impacts; growth normally precedes profitability. Also, some types of entrepreneurial initiatives may favor more clearly some performance measures instead of others (Wiklund and Shepherd, 2003). For example, family business venturing into international markets was associated negatively with ROA and ROS, as well as domestic venturing with EPS, while other innovations initiatives showed a positive association with those and other performance indicators (Zahra, et al., 2000).

\section{Laws of interaction}

The relationships among the units (concepts) of a theory are described in the theory's laws of interaction (Dubin, 1978). The laws of interaction show how changes in one or more units of the theory influence the remaining units. We show the relationships outlined in Figure 1. The work developed by Pearson et al. (2008) on familiness serves well to build a model that connects the social capital resources to entrepreneurship, and then to competitive advantage and performance.

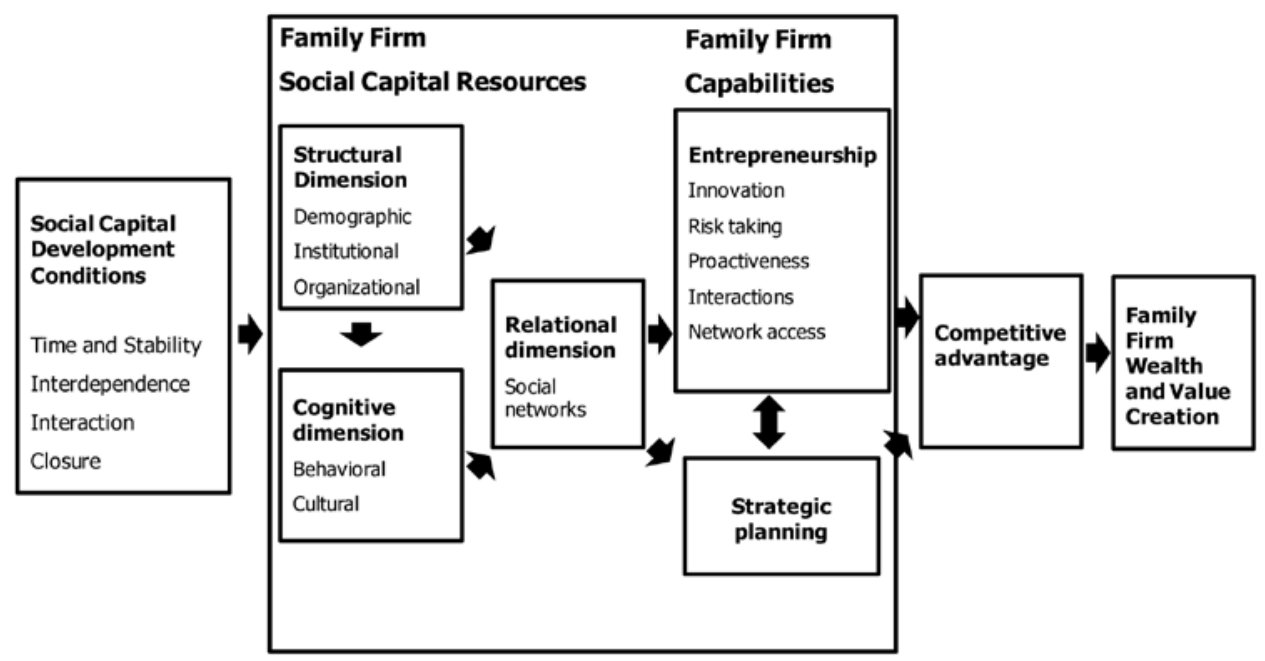

Figure 1. A Social Capital Model of Familiness for Entrepreneurship Source: Adapted from Pearson et al., 2008.

First, the social conditions that help create familiness (time and stability, interdependence, interaction, and closure) are presented, followed by the social 
capital resources, which comprise the structural dimension that accompanies entrepreneurship in the family business. Following Pearson et al. (2008), strength of ties is represented by demographic factors and generations involved in the business, while social interactions comprise institutional and organizational configurations, such as governance and ownership systems, communications, or delegation of authority patterns, among other organizational structural variables. These variables are circumscribed to a large extent to the components of involvement approach of family business.

The cognitive dimension comprises behavioral and cultural factors. These factors contribute to build shared representations and interpretations that provide meaning to family initiatives, according to Pearson et al. (2008), and are more related to the essence approach of family business. Within this same approach, the relational dimensions complement the social capital resources, including variables connected to social networks. These networks lead to personal interrelationships which are not limited to the context of the immediate family business members and help to build trust, norms, obligations and identity. Therefore, the interaction of the structural, cognitive, and relational dimensions conducts to the building of firm capabilities that, in case of our model, consist of the different activities related to entrepreneurship. By combining these dimensions, we are able to relate the components of involvement and the essence approaches to family business, as the basis for reaching family firm capabilities represented by entrepreneurship capacities.

However, even though there are various advantages that are related to family business, to reduce informality and non-systematic examination in defining and reaching entrepreneurial activities some mechanisms are needed. Therefore, we introduce the strategic planning process in the model as an appropriate mechanism between setting up entrepreneurial priorities and exploiting these initiatives in order to achieve competitive advantages in the market (Naldi et al., 2007). The strategic planning allows the firm's management to identify new opportunities that match business's resources and capabilities (Randel and Ward, 2001). These will form the basis on which competitive advantage is sustained that leads to enhanced firm performance, according to our proposed model.

\section{Boundaries of the model}

The boundaries of a theory distinguish its theoretical domain from aspects of the world that have not been considered by any other theory. The boundaries of a theory distinguish its theoretical domain from aspects of the world not addressed by the theory (Dubin, 1978). The entrepreneurship research has demonstrated that there are important commonalties with family business research (Chua, Chrisman, and Steier, 2003). Therefore, the domain of the model that we propose is the domain of family business, and it can be small, medium or big. 


\section{System States}

Dubin (1978) mentions that a system state that accurately represents a condition of the system being modeled has three characteristics: (a) all the units of the system are included in the system state (i.e., inclusiveness), (b) the relationship between units persists long enough to allow the goodness of fit between them to be determined (i.e., persistence), and (c) all units take on unique values for that system state (i.e., distinctiveness). We believe that our model has the three characteristics because: (a) it includes all the important units that have been identified as important in previous research on family business and entrepreneurship, (b) the relationships between all the units describe in Figure 1 are long-lasting relationships, and (c) there is no overlap in values between any of the units (i.e., each unit can be assigned a unique value)

\section{Propositions}

Yin (2002) argues that propositions are logical deductions about the theory in operation. Propositions are statements that are logically derived from theory; propositions can be subjected to empirical testing (Dubin, 1978). Derived from the literature review we can make the following research propositions. Although these propositions focus mainly on one of the capital social dimensions of the model, an interaction with the others is suggested, mainly the relational dimension and the planning strategic process.

We saw that participation of different family generations in the control or operations of the owner family tend to promote entrepreneurial activities. However we add that in order to flourish these initiatives, it is necessary that the company has established communication channels where participants can expose and discuss these ideas, as indicated by the factors included in the relational dimension. Based on these findings we can propose the following proposition:

P1: The higher the number of family owner's generations involved in the company, the higher the level of entrepreneurial activities, as mediated by social networks where owners and employees can interact.

It was seen that the involvement of the founders or owners in preparing and exposing successors to risk taking activities strengthen future leaders' capacities and skills to undertake entrepreneurial activities. Additionally the family support during the emergence phase of the idea is a key factor that affects the initiative success. Derived from these findings we can frame the following proposition:

P2: A more planned process for grooming and nurturing younger generation's risk-taking capability and capacity, and the family members support during the emergence phase of the entrepreneurial process, are associated with the successful continuance of the entrepreneurial initiative.

As seen there were certain conditions that promote a more entrepreneurial type of governance structure in the family business, mainly related to the board of directors. A greater size up to a certain number (11 members), a broader participation in the stock ownership, and a separation of the role CEO and the president of the board, create 
better opportunities for supporting entrepreneurial activities. However, as argued, the role of strategic planning structures and processes may capitalize that participation, introducing a more objective and analytical assessment of those initiatives. Based on this information the following proposition can be advanced:

P3: The set-up of ownership and governance structures and systems that promote broad participation and discussion in the family firms leads to higher levels of corporate entrepreneurship. In these processes, strategic planning can enhance the exploitation and success of entrepreneurship opportunities a family firm recognizes.

We reported an association between entrepreneurial activities and the way that family members in charge of the business evolve, from founder base to open family type. Also, organizational structural variables and the complexity of the environment affect the level of entrepreneurial activities in the family business. Based on these findings and according to the contribution that family members beyond those related directly with the business can make, we proposed the following proposition:

P4: The set-up of organizational structures that considers the type of firm in terms of family involvement (FC, CB or $\mathrm{OF}$ ) and environmental complexity in which these firms operate is linked to the presence of entrepreneurial activities. A higher instability of the environment may suggest a family participation in social networks beyond the boundaries of business family members.

Those studies that have focused on the behavioral aspects of family firms have emphasized the external and long term orientation of the family and its members as a condition for displaying higher levels of entrepreneurship. But in order to have the opportunity to build a shared understating and collective purpose, spaces must be created where human interaction takes place and networks are built, including the participation of non-family members working in the business. Thus, we can suggest the following proposition:

P5: A higher participation in social networks where owners and employees can interact leads to innovation and new ventures initiatives. Towards this purpose, the establishment of system and structures that give employees the opportunity to make contributions, while providing the mechanisms to integrate and coordinate these efforts, contribute to raise entrepreneurship.

Previous research about entrepreneurial orientation has found evidence that leads to the assumption that companies with entrepreneurial orientation has a better performance (Rauch, Wiklund, Lumpkin and Frese, 2009). However, Hart (1992) mentions that the results are not conclusive and although differences in results can be attributed to various research designs, the differences reflect the fact that the entrepreneurial orientation sometimes does not contribute for a better performance. Lumpkin and Dess (1996) argue that the strength of this relationship depends on internal characteristics and external to the organization, so the entrepreneurial orientation-firm performance relationship is more complex than a simple relationship. Therefore, we suggest the following proposition: 
P6: The relationship between entrepreneurial orientation of a family business and its performance is moderated by the strategic planning. The current competitive environment is complex, and complexity is derived from different dimensions, which makes short-term or long term decisions crucial to maintaining the competitiveness of family businesses.

\section{Discussion}

In making a distinction of the essence and components of involvement definitions of family business and familiness, we were able to build a conceptual model to group and connect those variables that associate family business to entrepreneurship. Through this theoretical construct of family business, we attain some important recommendations that argue for the need of a family embedded perspective on entrepreneurship (Aldrich and Cliff, 2003; Heck, Hoy, Poutziouris and Steier, 2008). However there are two aspects that we should take into account in relations to the scope and limitations of the proposed model and the theoretical propositions derived from it.

Firstly, one can argue that there are many more propositions that can be built from the reviewed literature that combines factors from those different dimensions. What we tried to do in elaborating these propositions was to base them on those findings that were more robust and replicated by various studies. We must admit that some of these propositions can be modified and adapted once the empirical research to be taken in the Mexican context is underway.

Secondly, contrary to the advantages posed by the social capital model of familiness for supporting entrepreneurship, some authors warn about the perils that surround family business that work against those entrepreneurial activities and their performance. According to these views, family involvement in a business increases agency costs due to challenges such as nepotism, free riding, family entrenchment, and intergenerational conflict, thereby negatively affecting performance (Lansberg, Perrow and Rogolsky, 1988; Gomez-Mejia, Nuñez-Nickel and Gutierrez, 2001; Miller, Le Breton-Miller, Lester and Cannella, 2007; Schulze et al., 2003). Moreover, Nordqvist (2005) argues that strategic proximity and persistence in the family firms can also lead to groupthink, alienation, and strategic simplicity. In trying to disentangle these opposing views, Rutherford, Kuratko and Holt (2008) examined the link between family and performance using the familiness instrument named familiness-power, experience, and culture (F-PEC) scale developed by Klein, Astrachan and Smyrnios (2005). As a result of empirical research, they found that the presence of high levels of familiness possesses some competitive advantages enhancing family firm qualities, and insisted that future studies work further to measure the essence of familiness as a mediator between involvement and performance. In a similar vein, the research undertaken by Sirmon, Arregle, Hitt and Webb, (2008) on how family firms take unique strategic actions in response to competitive threat of imitation to produce performance differences, also attempted to clarify those opposing views. Their 
results suggest that family influence (i.e. family managerial presence and ownership without providing unilateral control) might offer advantages to the firm (e.g. existence of patient capital) while mitigating weaknesses found in family-controlled firms (e.g. myopic tendencies) (Sirmon and Hitt, 2003). Therefore, family influence can help the firm achieve positive returns, but only when there are other views represented in the governance to balance the family views. In this way, the positive effects of family involvement are realized, but the other stakeholders are able to forestall the actions taken that could benefit the family to the detriment of the firm's performance. We believe that in the elaboration of the propositions we have been able to take variables that can provide a broader perspective that will allow us to prevent neglecting those possible factors that may act against entrepreneurship.

\section{Conclusions}

There have been many discussions about the factors associated with entrepreneurship or more properly, intrapreneurship in family business context. Sometimes, recommendations derived from these studies seem to contradict each other, reflecting different family business concepts and organizational contexts on which research was conducted, not to mention different institutional and cultural environments. To delve into these issues is not only a matter of academic interest, but also concerns practitioners, consultants, and those agencies that direct their efforts to promote entrepreneurial initiatives among small-and -medium sized enterprises, mainly family businesses.

This work allowed us to arrive at important research propositions that will be used for conducting research in entrepreneurship in family businesses in Mexico. However, we should recognize that the large majority of the studies on which the theoretical propositions were based came from research undertaken in other countries with different socioeconomic conditions and cultural patterns to the Mexican ones. However, on the one hand, the same concerns regarding how to promote entrepreneurship in family business and similar factors to the ones dealt with here that could be behind those entrepreneurial activities have been suggested in some Mexican studies (Cerutti, 2000; Hoshino, 2005; Pozas, 2002). On the other hand, we are quite aware that these research propositions are only an initial step towards revealing the nature of entrepreneurship in Mexican family firms. The nature of the research should be flexible enough to consider adaptations and modifications to the propositions framed as the research progresses (Eisenhardt, 1989: Eisenhardt and Graebner, 2007). The type of research to be developed will employ a case study approach as it is important to begin answering questions related to the why and how those family dimensions and variables are associated with entrepreneurship (Yin, 2002). 


\section{References}

Aldrich, H. E. and Cliff, J. E. (2003). The pervasive effects of family on entrepreneurship: Toward a family embeddedness perspective. Journal of Business Venturing, 18(5), 573-596.

Anderson, A. R., Jack, S. L. and Dodd, S. D. (2005). The role of family members in entrepreneurial networks: beyond the boundaries of the family firm. Family Business Review, 28(2), 135-154.

Arregle, J. L., Hitt, M. A., Sirmon, D. G. and Very, P. (2007). The development of organizational social capital: Attributes of family firms. Journal of Management Studies, 44(1), 72-.95.

Astrachan, J. and Shanker, M. (2003). Family businesses' contribution to the U.S. economy: A closer look. Family Business Review, 15(1), 45-48.

Becker, G. (1981). A treatise on the family. Cambridge, MA: Harvard University Press.

Birley, S., Ng, D. and Godfrey, A. (1999). The family and the business. Long Range Planning, 32(6), 598-608.

Cabrera, K. S., De Saá, P. P. and García, D. A. (2001). The Succession Process from a Resource- and Knowledge-Based View of the Family Firm. Family Business Review, 14(1), 37-48.

Cerutti, M. (2000). Propietarios, empresarios y empresa en el norte de México. México: Siglo XXI.

Chua, J. H., Chrisman, J. J. and Sharma, P. (1999). Defining the family business by behavior. Entrepreneurship Theory and Practice, 23(4), 19-39.

Chua, J. H., Chrisman, J. J. and Steier, L. P. (2003). Extending the theoretical horizons of family business research. Entrepreneurship Theory and Practice, 27(4), 331-338.

Davis J. A. and Tagiuri, R. (1989). The influence of life-stage on father on father-son relationship in family companies. Family Business Review, 2(1), 47-74.

Dubin, R. (1978). Theory building. 2nd ed. New York: Free Press.

Eisenhardt, K. M. (1989). Building theories from case study research. Academy of Management Review, 14(4), 532-550.

Eisenhardt, K. M. and Graebner, M. E. (2007). Theory building from cases: Opportunities and challenges. Academy of Management Journal, 50(1), 25-32.

Evald, M. R., Klyver, K. and Svendsen, S. G. (2006). The changing importance of the strength of ties throughout the entrepreneurial process. Journal of Enterprising Culture, 14(1), 1-26.

Fama, E. and Jensen, M. (1983), Separation of ownership and control. Journal of Law and Economics, 26(2), 301-325.

Gallo, M. (1995). The role of family business and its distinctive characteristic behavior in industrial activity. Family Business Review, 8(2), 83-97.

García-Tenorio, R. J. and Sánchez, Q. J. (2009). Amenazas y oportunidades: El reto de emprender en la empresa familiar. Gestión de empresa, 212, 66-77.

Gomez-Mejia, L., Nuñez-Nickel, M. and Gutierrez, I. (2001). The role of family ties in agency contracts. Academy of Management Journal, 44(1), 81-95. 
Grant, R. M. (1996). Toward a knowledge-based theory of the firm. Strategic Management Journal, 17, 109-122.

Habbershon, T. and Williams, M. (1999). A resource-based framework for assessing the strategic advantages of family firms. Family Business Review, 12(1), 1-25.

Habbershon, T., Williams, M. and MacMillan, I. (2003). A unified systems perspective of family firm performance. Journal of Business Venturing, 18(4), 451-465.

Hart, S. L. (1992). An integrative framework for strategy-making process. Academy of Management Review, 17(2), 327-351.

Haynes, G., Walker, R., Rowe, B. and Hong, G. (1999). The intermingling of business and family finances in family-owned businesses. Family Business Review, 12(3), 225-239.

Heck, R. Z., Hoy, F., Poutziouris, P. Z. and Steier, L. P. (2008), Emerging paths of family entrepreneurship research. Journal of Small Business Management, 26(3), 317-330.

Hitt, M. A. \& Ireland, R. D. (1985). Corporate distinctive competence, strategy, industry and performance. Strategic Management Journal, 6(3), 273-293.

Hoshino, T. (2005). Executive Managers in Large Mexican Family Businesses. Discussion paper. Institute of Developing Economies, JETRO, pp. 144.

Jensen, M. C. and Meckling, W. F. (1976). Theory of the firm: Managerial behavior, agency costs and ownership structure. Journal of Financial Economics, 3(4), 305360.

Johannisson, B. (2003). Entrepreneurship as a collaborative phenomenon, in Genescà, E., Urbano, D., Capelleras, J., Guallarte, C. and Vergès, J. (Eds), Creación de EmpresasEntrepreneurship, Servei de Publicaciones de la Universitat Autónoma de Barcelona, Barcelona, 87-109.

Kellermanns, F. W. and Eddleston, K. A. (2006). Corporate entrepreneurship in family firms: A family perspective. Entrepreneurship Theory and Practice, 30(6), 809-830.

Kellermanns, F. W., Eddleston, K. A., Barnett, T. and Pearson, A. (2008). An exploratory study of family member characteristics and involvement: Effects on entrepreneurial behavior in the family firm. Family Business Review, 21(1), 1-14.

Klein, S. B., Astrachan, J. H. and Smyrnios, K. X. (2005). The F-PEC scale of family influence: Construction, validation, and further implication for theory. Entrepreneurship Theory and Practice, 29(3), 321-339.

Klyver, K. (2007). Shifting family involvement during the entrepreneurial process. International Journal of Entrepreneurial Behaviour \& Research, 13(5), 258-277.

Lansberg, I., Perrow, E. L. and Rogolsky, S. (1988). Family business as an emerging field. Family Business Review, 1(1), 1-6.

Leach, P. (1993). La empresa familiar. Barcelona: Ediciones Granica.

Leana, C. R. and Van Buren, H. J. (1999). Organizational social capital and employment practices. Academy of Management Review, 24(3), 538-555.

Litz, R. A. (1995). The family business; Towards definitional clarity. Family Business Review, 8(1), 71-81.

Lumpkin, G. T. and Dess, G. (1996). Clarifying the entrepreneurial orientation construct and linking it to performance. Academy of Management Review, 21(1), 135-173. 
Miller, D. (1983). The correlates of entrepreneurship in three types of firms. Management Science, 29(7), 770-791.

Miller, D., Le Breton-Miller, I., Lester, R. H. and Cannella, A. A. (2007). Are family firms really superior performers? Journal of Corporate Finance, 13(5), 829-858.

Mintzberg, H. (1973). Strategy-Making in Three Modes. California Management Review, 16(2), 44-53.

Mintzberg, H. (1979). The Structuring of Organizations, Prentice-Hall, Englewood Cliffs, N.J. Morris, M. H. (1998). Entrepreneurial intensity. Westport, CT: Quorum Books.

Myers, S. (1977). The determinants of borrowing. Journal of Financial Economics, 5(2), 147-175.

Nahapiet, J. and Ghoshal, S. (1998). Social capital, intellectual capital, and the organizational adavantage. Academy of Management Review, 23(2), 242-266.

Naldi, L., Nordqvist, M., Sjöberg, K. and Wiklund, J. (2007). Entrepreneurial orientation, risk taking, and performance in family firms. Family Business Review, 20(1), 33-47.

Nordqvist, M. (2005). Familiness in top management teams: Commentary on Ensley and Pearson's "An exploratory comparison of the behavioral dynamics of top management teams in family and nonfamily new ventures: cohesion, conflict, potency, and consensus". Entrepreneurship Theory and Practice, 29(3), 285-291.

Oh, H., Labianca, G. and Chung, M. (2006). A multi-level model of group social capital. Academy of Management Review, 31(3), 569-582.

Pearson, A. W., Carr, J. C. and Shaw, J. C. (2008). Toward a theory of families: A social capital perspective. Entrepreneurship Theory and Practice, X(X), 949-969.

Penrose, E. T. (1959). The theory of the growth of the firm. New York: John Wiley.

Pollack, R. (1985). A transaction cost approach to families and households. Journal of Economic Literature, 23, 581-608.

Pozas, Maria de los Angeles (2002). Estrategia internacional de la gran empresa mexicana de la década de los noventa. México: El Colegio de México.

Randel S. C. \& Ward, J. L. (2001). La Planificación Estratégica de la Familia Empresaria. España, Deusto, IEF, PwC.

Rauch, A. J., Wiklund, G., Lumpkin, T. and Frese, M. (2009). Entrepreneurial Orientation and Business Performance: Cumulative Empirical Evidence. Entrepreneurship Theory and Practice, 33(3), 761-788.

Ribeiro-Soriano, D. \& Urbano, D. (2009). Overview of collaborative entrepreneurship: an integrated approach between business decisions and negotiations. Group Decision and Negotiation, 18(5), 419-430.

Rutherford, M. W., Kuratko, D. F. and Holt, D. T. (2008). Examining the link between "familiness" and performance: Can the F-PEC untangle the family business theory jungle? Entrepreneurship Theory and Practice, 32(6), 1089-1109.

Salvato, C. (2004). Predictors of Entrepreneurship in Family Firms. The Journal of Private Equity, $X(X), 68-76$.

Schulze, W. S., Lubatkin, M. H. and Dino, R. N. (2001). Agency relationships in family firms: Theory and evidence. Organization Science, 12(2), 99-116. 
Schulze, W. S., Lubatkin, M. H. and Dino, R. N. (2003). Toward a theory of agency and altruism in family firms. Journal of Business Venturing, 18(4), 473-490.

Shepherd, D. and Haynie, J. M. (2009). Family business, Identity conflict, and an expedited entrepreneurial process: A process of resolving identity conflict. Entrepreneurship Theory and Practice, 33(6), 1245-1264.

Shleifer, A. and Vishny, R. (1997). A survey of corporate governance. Journal of Finance, 52(2), 737-783.

Sirmon, D. G. and Hitt, M. A. (2003). Managing resources: Linking unique resources, Management, and wealth creation in family firms. Entrepreneurship Theory and Practice, 27(4), 339-358.

Sirmon, D. G., Arregle, J. L., Hitt, M. A. and Webb, J. W. (2008). The role of family influence in firms' strategic responses to threat of imitation. Entrepreneurship Theory and Practice, 32(6), 979-998.

Toledano, N., Urbano, D. and Bernadich, M. (2010). Networks and corporate entrepreneurship. A comparative case study on family business in Catalonia. Journal of Organization Change Management, 23(4), 396-412

Wang, Y. and Poutziouris, P. (2010). Entrepreneurial risk taking: empirical evidence from UK family firms. International Journal of Entrepreneurial Behaviour \& Research, 16(5), 370-388.

Ward, J. L. (1987). Keeping the family business healthy. San Francisco: Jossey-Bass.

Wernerfelt, B. (1984). A resource-based view of the firm. Strategic Management Journal, 5(2), 171-180.

Wiklund, J. and Shepherd, D. (2003). Knowledge-Based Resources, Entrepreneurial Orientation, and The Performance of Small and Medium-Sized Businesses, Strategic Management Journal, 24(13), 1307-1314.

Yin, R. K. (2002). Case Study Research: Design and Methods. $3^{\text {rd }}$ ed. Thousands Oaks, CA: Sage.

Zahra, S. A. (2005). Entrepreneurial risk taking in family firms. Family Business Review, 18(1), 23-40.

Zahra, S. A., Neubaum, D. O. and Huse, M. (2000). Entrepreneurship in medium-size companies: Exploring the effects of ownership and governance systems. Journal of Management, 26(5), 947-976.

Zahra, S. A., Hayton, J. C. and Salvato, C. (2004). Entrepreneurship in family vs. nonfamily Firms: A resource-based analysis of the effect of organizational culture. Entrepreneurship Theory and Practice, 28(4), 363-381.

\section{Abstract (in Polish)}

Niniejsza praca jest oparta o dotychczasowe badania teoretyczne i empiryczne w zakresie zarządzania i przedsiębiorczości firm rodzinnych. Praca proponuje model badawczy oparty o teorię Dubina dla prowadzenia badań nad firmami rodzinnymi i omawia jego zwiqzek z przedsiębiorczościq w Meksyku. Praca podejmuje tematykę podstawowych koncepcji w zakresie rodzinnego biznesu i wyjaśnia wpływ podstawowych pojęć na dobór 
zmiennych wykorzystanych w modelu badawczym. Następnie, praca wyjaśnia w jaki sposób "rodzinność" wiq̨że się z zasadniczq definicjq biznesu rodzinnego. W oparciu o spojrzenie oparte o zasoby (ang. resource-based view (RBV)), agency theory i teorie społecznego kapitału (ang. social capital theories) praca wyjaśnia w jaki sposób społeczne zasoby kapitałowe stanowiq podstawę budowania zdolności firmy i jej przewagi konkurencyjnej. W oparciu o takq perspektywę, praca proponuje teoretyczny model, dyskutuje prawa oddziaływania między zmiennymi i nakreśla kierunki dla przyszłych badań w tym zakresie.

Słowa kluczowe: teoria Dubina, przedsiębiorczość rodzinna, rodzinność, teoria zasobowa, przewaga konkurencyjna. 